University of Nebraska - Lincoln

DigitalCommons@University of Nebraska - Lincoln

\title{
Frankliniella occidentalis (Pergande) integrated pest management programs for fruiting vegetables in Florida
}

\author{
Ozan Demirozer \\ Suleyman Demirel University, ozandemirozer@sdu.edu.tr \\ Kara Tyler-Julian \\ University of Florida \\ Joe Funderburk \\ University of Florida, jef@ufl.edu \\ Norm Leppla \\ University of Florida, ncl@ifas.ufl.edu \\ Stuart Reitz \\ USDA-ARS, Stuart.reitz@ars.usda.gov
}

Follow this and additional works at: https://digitalcommons.unl.edu/usdaarsfacpub

Demirozer, Ozan; Tyler-Julian, Kara; Funderburk, Joe; Leppla, Norm; and Reitz, Stuart, "Frankliniella occidentalis (Pergande) integrated pest management programs for fruiting vegetables in Florida" (2012). Publications from USDA-ARS / UNL Faculty. 1097.

https://digitalcommons.unl.edu/usdaarsfacpub/1097

This Article is brought to you for free and open access by the U.S. Department of Agriculture: Agricultural Research Service, Lincoln, Nebraska at DigitalCommons@University of Nebraska - Lincoln. It has been accepted for inclusion in Publications from USDA-ARS / UNL Faculty by an authorized administrator of DigitalCommons@University of Nebraska - Lincoln. 


\title{
Frankliniella occidentalis (Pergande) integrated pest management programs for fruiting vegetables in Florida
}

\author{
Ozan Demirozer, ${ }^{a *}$ Kara Tyler-Julian, $^{\mathrm{b}}$ Joe Funderburk, ${ }^{\mathrm{b}}$ Norm Leppla $^{\mathrm{c}}$ \\ and Stuart Reitz ${ }^{d, e}$
}

\begin{abstract}
BACKGROUND: The spread of the western flower thrips, Frankliniella occidentalis (Pergande) (Thysanoptera: Thripidae), resulted in the worldwide destabilization of established integrated pest management programs for many crops. Efforts to control the pest and the thrips-vectored tospoviruses with calendar applications of broad-spectrum insecticides have been unsuccessful. The result has been a classic ' $3-R^{\prime}$ situation: resistance to numerous insecticides; resurgence of the western flower thrips populations as a result of natural predators and native competitor thrips being eliminated; replacement by various other pests. This paper reports on integrated pest management programs for fruiting vegetables that are effective, economical, ecologically sound and sustainable.

RESULTS: The components include the following: define pest status (economic thresholds); increase biotic resistance (natural enemies and competition); integrate preventive and therapeutic tactics (scouting, ultraviolet-reflective technologies, biological control, compatible insecticides, companion plants and fertility); vertically integrate the programs with other pests; continually communicate latest science-based management tactics with end-users.
\end{abstract}

CONCLUSION: These programs have been widely implemented in Florida and have significantly improved the management of western flower thrips and thrips-transmitted viruses.

(c) 2012 Society of Chemical Industry

Keywords: thrips; integrated pest management; Frankliniella occidentalis; fruiting vegetables; tospovirus

\section{INTRODUCTION}

There are over 5000 species of thrips (order Thysanoptera), and 87 are considered to be pests of commercial crops. ${ }^{1}$ Injury to leaves, fruits and flowers is caused during the feeding process, in which the adults and larvae pierce the plant with the mandible and extract the contents of ruptured cells. Additional injury to leaves, flowers and fruits may occur during the oviposition process when the egg is inserted into the plant's tissue with the subsequent emergence of the larva. ${ }^{2}$ Numerous species also vector viral pathogens, in addition to the mechanical damage they inflict on the plants. ${ }^{3}$

\section{THRIPS AND TOSPOVIRUSES AS PESTS OF FRUITING VEGETABLES}

In Florida there are two common native species of thrips found in the flowers of crops. These are eastern flower thrips [Frankliniella tritici (Fitch)], which is the most common species in northern Florida, ${ }^{4}$ and Florida flower thrips [Frankliniella bispinosa (Morgan)], which is the most common species in south and central Florida. ${ }^{5}$ Other species of thrips found on Florida vegetable crops in much lower numbers include tobacco thrips [Frankliniella fusca (Hinds)] in northern Florida and Frankliniella schultzei (Trybom) in central and southern Florida. ${ }^{5}$ In addition to these species of thrips, there have been a few recent thysanopteran invaders in Florida, including chilli thrips, Scirtothrips dorsalis (Hood), Megalurothrips mucunae (Priesner) on legumes ${ }^{6}$ and melon thrips, Thrips palmi Karny. Whereas these aforementioned thrips have not been of major concern for vegetable production, one invasive species is present that poses a major threat to Florida farmers: western flower thrips [Frankliniella occidentalis (Pergande)].

Western flower thrips is native to the southwestern United States but has spread to other parts of the country and the world, beginning in the 1980s, likely owing to global trade in greenhouse plants. ${ }^{7}$ While western flower thrips has been established in

\footnotetext{
Correspondence to: Ozan Demirozer, Suleyman Demirel University, Faculty of Agriculture, Department of Plant Protection, 32260 Isparta, Turkey.

E-mail: ozandemirozer@sdu.edu.tr

a Suleyman Demirel University, Faculty of Agriculture, Department of Plant Protection, Isparta, Turkey

b University of Florida, Quincy, FL, USA

c University of Florida, Gainesville, FL, USA

d Center for Medical, Agricultural and Veterinary Entomology, Agricultural Research Service, USDA, Tallahassee, FL, USA

e Oregon State University, Ontario, OR, USA
} 
northern Florida since the early 1980s, it did not become an economic problem in central and southern Florida until $2005 .{ }^{8}$ The damage caused by western flower thrips is twofold: aesthetic damage caused by excessive levels of injury due to feeding and oviposition, and plant disease caused by tospovirus transmission. Worldwide western flower thrips is the major vector of tomato spotted wilt virus and Impatiens necrotic spot virus, and it is also a vector of chrysanthemum stem necrosis virus, groundnut ringspot virus and tomato chlorotic spot virus. ${ }^{9,10}$

Eastern flower thrips, western flower thrips and Florida flower thrips all exhibit thigmotactic behavior. For this reason they can be found aggregating in flowers as adults, and as larvae they can be found in flowers and on fruits, often choosing to hide under the calyx on the fruit or in places of contact between fruits and stems or leaves. ${ }^{5,11}$ Western flower thrips is a phytophagous species that feeds and reproduces on many species of cultivated and uncultivated plants. The adults feed on the pollen and flower tissues, and the female lays individual eggs in the small developing fruit of some crops, such as tomato. After the egg hatches, a small dimple often remains on the developing fruit, which may or may not be surrounded by a halo. This dimple will remain on the developing fruit long after the egg hatches. ${ }^{12}$ In addition to this initial oviposition injury, the larvae will continue to feed on the fruit, causing an additional injury referred to as 'flecking'. ${ }^{13}$

Although the injury to the fruits by western flower thrips can be aesthetically damaging, and lead to cull-out and downgrading, ${ }^{13}$ the more serious threat is the capability of western flower thrips to vector various tospoviruses. For Florida vegetable growers the most serious and widespread pathogen vectored by western flower thrips is tomato spotted wilt virus, estimated to cost farmers \$US 1 billion in crop losses annually. ${ }^{14}$ The most common symptom of the virus is necrotic spots, streaks or rings on the leaves or fruits. The severity of the symptoms can range from flecks on the fruit to necrotic lesions, and ultimately plant death.

At least eight species of thrips are capable of transmitting tomato spotted wilt virus: F. bispinosa, F. cephalica (Crawford), F. fusca, Frankliniella intonsa (Trybom), F. occidentalis, F. schultzei, Thrips setosus Moulton and Thrips tabaci Lindeman, and S. dorsalis. ${ }^{9}$ There are 19 species of tospovirus, of which tomato spotted wilt virus is the type species. All of the tospoviruses are transmitted exclusively by thrips. Tomato spotted wilt virus is currently known to infect more than 900 species of plants, cultivated and uncultivated. ${ }^{15}$ For adults to be competent vectors, tospoviruses must be first acquired by the larvae while feeding on an infected plant. Upon becoming adults, these infected thrips can transmit tospoviruses to uninfected plants within seconds of feeding on them. The adults persistently transmit once they have acquired the tospovirus as larvae. Tomato spotted wilt virus has a mutual relationship with the western flower thrips: thrips larvae have a higher survival rate and develop more quickly on infected plants. ${ }^{16}$ Additionally, plants infected with the virus are more attractive to thrips, which preferentially feed and oviposit on the infected plants over uninfected plants. ${ }^{17}$

Tomato spotted wilt virus is spread in two stages: primary infection and secondary infection. Primary infection refers to infection that occurs when a viruliferous adult capable of transmiting a tospovirus arrives in a new field and begins to feed on the plants, thereby infecting them with the disease. Secondary spread occurs when the adults reproduce on infected plants within a field, and the larvae acquire the tospovirus.
After developing to adult, the thrips transmit the virus to other uninfected plants within the same field. ${ }^{18}$ Pesticides are not effective at reducing primary spread owing to the small amount of feeding time needed for transmission to occur. ${ }^{18}$ Therefore, repellent strategies are needed to prevent the adults from entering fields and feeding. The most effective way to reduce secondary spread is by controlling larvae. The majority of infections in northern Florida tomatoes are caused by primary infection. $^{18}$

The population attributes of reproduction on numerous plant species in many plant families, high fecundity, rapid generation time and high dispersal capability provide for an extraordinary ability of the western flower thrips to exploit ephemeral crop resources. Populations are able to continue rapid build-up, in spite of attempts to control them by repeated application of conventional insecticides. ${ }^{19}$ In the past, farmers worldwide typically have utilized calendar applications of broadspectrum insecticides in an effort to control all species of thrips. Unfortunately, this method has not been successful, and, in addition to economic damage from the cost of overusing pesticides, farmers have suffered losses of crops to disease epidemics and direct damage from high populations. ${ }^{20}$ This results in a ' $3-R^{\prime}$ situation for western flower thrips: resistance to numerous insecticides; resurgence of the western flower thrips populations as a result of natural predators and native competitor thrips being eliminated; replacement by various other pests. ${ }^{21}$ Morse and Hoddle ${ }^{22}$ concluded that the spread of the western flower thrips and species of tospoviruses has resulted in the worldwide destabilization of established integrated pest management programs for many crops grown in the field and greenhouse. Cloyd ${ }^{23}$ suggested an impasse in managing the western flower thrips in ornamental greenhouse production.

Western flower thrips has a propensity for developing resistance to many classes of insecticides. The means by which western flower thrips develops pesticide resistances have been reviewed in a recent paper by Gao et al. ${ }^{24}$ The polyphagous nature of thrips likely results in their predisposition to evolve resistance through metabolic detoxification pathways. These pathways allow the insect to contend with an array of defensive chemicals when traveling from host to host. ${ }^{25}$ This adaptation continues to benefit the western flower thrips, as it enables them efficiently to develop resistance through these same pathways to numerous classes of insecticides, ${ }^{26,27}$ including carbamate, organochlorine, organophosphate and pyrethroid insecticides. ${ }^{28}$ The resistance to pyrethroids through these metabolic detoxification pathways has occurred worldwide and tends to occur rapidly. ${ }^{8,26-31}$ Resistance to insecticides can derive from more than one trait and can develop from more than one pathway, and multiple pathways can combine to contribute to each pesticide resistance. ${ }^{32}$ These many factors have led to a large number of modes by which western flower thrips has developed resistances to many individual pesticides and combinations thereof. Additionally, western flower thrips may maintain resistance for long periods of times in the absence of pesticides, without any obvious fitness disadvantages. ${ }^{33-36}$

It is evident that there are many factors that render pesticides ineffective in the short or long term in controlling the western flower thrips and tospoviruses. Furthermore, control approaches affect survivorship of non-target organisms. A sound integrated pest management approach demands that as much as possible is learnt about the biology of western flower thrips and its 
Table 1. Recommendations for managing western flower thrips in pepper and eggplant (adapted from Funderburk et al. $^{38}$ )

1 In the scouting program, distinguish between adult and larval thrips and identify the adult thrips to species

2 Economic thresholds: about six western flower thrips per flower or about two thrips larvae per fruit (identifying species of larvae is not necessary - all are equally damaging)

3 Do not treat for Florida flower thrips and eastern flower thrips, as they outcompete western flower thrips

4 From transplanting until early fruit set, use insecticides for western flower thrips and other pests that conserve minute pirate bugs

5 From transplanting until early fruit set, do not use insecticides that induce western flower thrips

6 Ultraviolet-reflective mulch when forming beds and foliar applications of kaolin clay repel thrips

7 Sunflower and other refugia plants provide a source for minute pirate bugs

8 Vertically integrate the management of western flower thrips and other pests, including pepper weevil and Lepidoptera

9 Follow best management practices for fertility

relationships to crops, including its pest status. Good integrated pest management recognizes that western flower thrips and different organisms are interdependent, and that disrupting this pest's populations will affect competing species, natural enemies and non-target pests. The objectives of an integrated pest management program are that it be effective, economical, ecologically sound and sustainable.

A well-executed integrated pest management strategy is critical for providing the best means of dealing with damage from the thrips and tospoviruses. Integrated pest management programs for fruiting vegetables that have been designed to meet the abovementioned requirements for western flower thrips are described below. The components of these programs are based on 25 years of scientific and technological research in northern Florida, where western flower thrips and tomato spotted wilt virus became the key pest problems in fruiting vegetables and other crops in 1985. The programs have been modified for conditions in central and southern Florida, as problems from western flower thrips and tospoviruses emerged there in $2006 .{ }^{8}$ The components include the following: define pest status (economic thresholds); increase biotic resistance (natural enemies and competition); integrate preventive and therapeutic tactics (scouting, ultravioletreflective technologies, biological control, compatible insecticides, companion plants and fertility); vertically integrate the programs with other pests; continually communicate with end-users. The specific recommendations for western flower thrips management in pepper and eggplant production are listed in Table 1, and the specific recommendations for tomato are listed in Table 2. Each of the recommendations is described in the text that follows.

\section{INTEGRATED PEST MANAGEMENT PRO- GRAMS FOR THRIPS AND TOSPOVIRUSES IN FRUITING VEGETABLES IN FLORIDA \\ 3.1 Scouting}

Different species of thrips vary greatly in their pest status to fruiting vegetables in Florida, either as vectors of tospoviruses or in their ability to cause feeding and oviposition injury. Therefore,
Table 2. Recommendations for managing western flower thrips in tomato (adapted from Funderburk et $a l^{37}$ )

1 In the scouting program, distinguish between adult and larval thrips and identify the adult thrips to species

2 Economic thresholds: about one western flower thrips per flower or about two thrips larvae per fruit (identifying species of larvae is not necessary - all are equally damaging)

3 Do not treat for Florida flower thrips and eastern flower thrips, as they outcompete western flower thrips

4 Avoid using insecticides that induce western flower thrips

5 Ultraviolet-reflective mulch when forming beds and foliar applications of kaolin clay repel thrips

6 Vertically integrate the management program for thrips with the management of other pests and diseases, including whiteflies and Lepidoptera and whitefly-vectored viruses and other tomato diseases

7 Follow best management practices for fertility

determination of adults to species is important information in management programs. Estimating densities of adults of each species and the total number of larvae in flowers and on fruits is recommended for scouting programs of tomato, pepper and eggplant. ${ }^{37,38}$ Identification is a challenge, as scouts need training and stereoscopes with at least $40 \times$ magnification to discern the morphological characters that differentiate species commonly found in crops. These characters include the number, arrangement and size of setae on the thrips pronotum, head and antennae. Training workshops and publications for endusers must be maintained and extended continually by university specialists. In Florida, these activities are facilitated with the cooperation of the Southern Plant Diagnostic Laboratory at the University of Florida. ${ }^{39}$ In spite of the challenge, identification of thrips adults in scouting programs has been successfully implemented. Populations of natural enemies of thrips, namely minute pirate bugs (Orius species), are monitored, as they are a natural defense against thrips populations and secondary virus spread. $^{40}$

\subsection{Economic thresholds}

Understanding the pest/crop damage relationship and defining pest status is the prime ingredient of any decision-making approach in integrated pest management. ${ }^{41}$ For that reason, economic thresholds have been developed for flower thrips species in tomato, pepper and eggplant. ${ }^{20,37,38}$ These economic thresholds are useful in determining the short-term need in a particular crop to apply therapeutic control of thrips to minimize dimpling, flecking or secondary spread of tospoviruses. Economic thresholds also help to define pest status and risk to the producer over multiple cropping seasons. Combined over seasons, scouting information on population levels of western flower thrips relative to the economic threshold and on the incidences of the plants infected by tospoviruses allows the grower to evaluate the need to employ preventive tactics in the future.

Eastern flower thrips and Florida flower thrips adults are not damaging to fruiting vegetables, and these native species are beneficial because they outcompete western flower thrips. ${ }^{42}$ Even densities of 20-25 adults per flower of the two native species have been shown not to result in damage to tomato, pepper or eggplant; $20,37,38$ however, western flower thrips adults of more than one per flower can cause damage from dimpling in tomato. 
Dimpling is not a damage issue for pepper or eggplant. However, it is recommended that adult populations of western flower thrips of about six per flower is an indication that larval populations will very soon exceed economic thresholds on the fruits of pepper and eggplant. Two larvae per fruit of any species is the economic threshold below which damage from flecking on tomato, pepper and eggplant fruits does not occur. It is at these thresholds of more than one adult western flower thrips per tomato flower, more than six western flower thrips adults per pepper or eggplant flower and more than two larvae per tomato, pepper or eggplant fruit that growers should take therapeutic action. Therapeutic control of the adult vectors of tospoviruses is not effective in preventing transmission of tospoviruses, but control of the larvae is effective in preventing secondary spread. ${ }^{18}$ Therefore, the economic threshold of larvae on fruit is important in management of tospoviruses when an epidemic is developing in a field.

\subsection{Natural enemies}

A biologically based integrated pest management program is fundamental in preventing the development of insecticide resistance, resurgence of western flower thrips populations and replacement with secondary pest damage. ${ }^{43}$ The conservation biological control component of the integrated pest management program is the most effective way to manage thrips in pepper and eggplant. ${ }^{19,20,40}$ Many predaceous arthropod groups help to suppress thrips populations. Species of Anthocoridae are the most important predators of thrips worldwide. Within this family are minute pirate bugs, with two species in Florida, Orius insidiosus (Say) and Orius pumilio (Champion), that are the key natural enemies of thrips in eggplant and pepper. ${ }^{20}$

Minute pirate bugs are valuable for managing thrips, as they prey preferentially on the adults of western flower thrips over adults of the non-damaging native thrips species. ${ }^{44,45}$ Thrips larvae are preferred prey. ${ }^{44}$ About one minute pirate bug for every 180 thrips is sufficient for suppression of populations of thrips. At a ratio of about one predator to 40 thrips, thrips populations are controlled. Natural populations of minute pirate bugs are highly vagile. ${ }^{46}$ The adults rapidly invade pepper and eggplant fields in Florida in sufficient numbers to control western flower thrips adults and larvae, but they must be conserved with judicious insecticide use. ${ }^{20}$ Because tomato is a non-preferred, poor reproductive host for minute pirate bugs, natural populations are not sufficient to provide control of western flower thrips in that particular crop. $^{47-49}$

Other thrips predators include the big-eyed bugs (family Lygaeidae), damsel bugs (family Nabidae), lacewings (family Chrysopidae), predatory thrips (primarily in the family Aeolothripidae) and predatory mites (family Phytoseiidae). Natural populations of these predatory groups do not typically invade fields of fruiting vegetables in sufficient numbers to suppress thrips populations. However, to demonstrate the impact that predators can exert on thrips populations, Reitz et al. ${ }^{40}$ showed that commercially grown and released populations of Geocoris punctipes (Say) reduced western flower thrips in pepper. Likewise, repeated release of the predaceous mite Amblyseius swirskii (Athias-Henriot) at a rate as low as 12 mites per plant controls western flower thrips, whiteflies and broad mites in pepper and eggplant. If released early in the plant cycle at this rate, these mites are sufficient to provide control for more than a month.

\subsection{Companion plantings}

Various plant species offer habitat for important natural enemies of thrips and other insects. ${ }^{50}$ Numerous plant species have been shown to attract enough natural enemies to manage western flower thrips populations. ${ }^{51,52}$ In Florida, Bidens alba, sunflowers, Wedelia trilobata and two species of clover are hosts for minute pirate bugs and other natural enemies, ${ }^{53}$ and plantings near crops of fruiting vegetables increase biological control of thrips. ${ }^{8}$ Queen Anne's lace, Daucus carota, and false Queen Anne's lace, Ammi majus, are also good hosts for Orius species, likely because of the presence of alternative prey and pollen as food sources. ${ }^{54}$ Additionally, these and other wild plant species around fields serve as hosts for the non-damaging native thrips species ${ }^{55}$ that are competitors of the western flower thrips. ${ }^{42}$ Because western flower thrips are outcompeted by the native thrips species, and because they suffer preferential predation by minute pirate bugs, companion plantings of these plant species are not sources for damaging populations of western flower thrips. Studies are currently being conducted to gain a better understanding of the benefits of different species of plants to serve as banker or refugia plants for minute pirate bugs and other important natural enemies. Further, different species of companion plants that are more attractive to western flower thrips than crops of fruiting vegetables are being evaluated. These studies have shown that species of Bidens and Helianthus are suitable in a combined push/pull strategy, with ultraviolet-reflective mulches and kaolin clay acting as the push to manage western flower thrips and tospoviruses in fruiting vegetables.

\subsection{Ultraviolet-reflective technologies}

Preventive tactics are available that hinder the western flower thrips and other pests from colonizing fruiting vegetable crops. Thrips locate host plants primarily through a combination of visual cues, with anthophilous thrips attracted to colors of flowers. Western flower thrips are attracted to spectral radiation in the ultraviolet range $(\sim 365 \mathrm{~nm})$ and in the yellow-green range $(\sim 540 \mathrm{~nm}) .{ }^{56}$ The yellow-green sensitivity is thought to play a role in long-distance orientation to plants, and the ultraviolet sensitivity assists with distinguishing flowers. Consequently, increasing the reflectivity in the ultraviolet range of the spectrum repels thrips. The ultraviolet-reflective mulches available for the raisedbed plastic mulch production system are effective in repelling colonizing adults of western flower thrips, and this repellency reduces the primary and secondary spread of tomato spotted wilt virus. The use of ultraviolet-reflective mulch also reduces the influx of the native thrips, eastern flower thrips and Florida flower thrips, but not disproportionately to reductions in western flower thrips. ${ }^{18,40}$ Ultraviolet-reflective mulches also deter other pests, especially whiteflies and aphids, which can vector other plant viruses. ${ }^{57-59}$ Ultraviolet-reflective mulches affect the underlying soil temperatures, which may positively or negatively alter plant growth and yield. Because of their aluminized surface, ultravioletreflective mulches are more expensive and difficult to dispose of than standard plastic mulches. ${ }^{60,61}$ Ultimately, the costs/benefits of the technology must be weighed for each particular circumstance (Reitz SR, unpublished data). ${ }^{62,63}$

Ultraviolet-reflective mulches are most effective early in the crop season before the plant canopy begins to cover the mulch, thereby reducing the surface area available for reflectance. ${ }^{18,40}$ Application of certain fungicides and other pesticides reduces the ultraviolet reflectance and hence the efficacy of the mulch. A single 
application of copper and mancozeb fungicide can reduce the reflectance by about 49\% (Reitz SR, unpublished data). Commercial formulations of kaolin clay sprayed onto fruiting vegetables also repel thrips, and foliar applications reduce western flower thrips colonization and the subsequent spread of tospoviruses (TylerJulian K, Funderburk JE, Demirozer O and Reitz SR, unpublished).

\subsection{Fertility}

Growers historically have overfertilized crops by up to $70 \% .{ }^{64}$ Extra nitrogen fertilization above the recommended optimal amount increases densities of western flower thrips. Female western flower thrips, in particular, preferentially settle on plants with higher nitrogen content. ${ }^{49,65}$ As vector populations expand with increasing fertilization, there is an upsurge in the incidence of tomato spotted wilt virus. In north Florida tomatoes, the incidence of tomato spotted wilt virus was $50 \%$ lower for plants grown at recommended nitrogen levels compared with plants grown with supraoptimal nitrogen. ${ }^{66}$ In contrast, eastern flower thrips and Florida flower thrips do not respond in the same manner to nitrogen fertilization as western flower thrips. ${ }^{49,66}$ Therefore, growers improve overall crop production of tomatoes and pepper by maintaining recommended fertilization levels.

\subsection{Acibenzolar-S-methyl}

Many plants possess traits for systemic acquired resistance, which are induced defensive mechanisms against pathogens. ${ }^{67}$ Certain chemicals have been found to stimulate these natural plant defenses against pathogens when applied to plants before infection occurs. The benzothiadiazole acibenzolar-S-methyl is a systemic acquired resistance inducer that stimulates the salicylic acid pathway for disease resistance in tomato and other crops. Commercial formulations of acibenzolar-S-methyl have been shown to reduce the incidence of tomato spotted wilt, although its use has minimal impacts on populations of thrips. ${ }^{18}$ The commercial product is particularly effective against bacteria, and it is a replacement for foliar pesticides for bacterial and fungal disease control.

\subsection{Host plant resistance}

Numerous cultivars of tomato and pepper that are resistant or tolerant to tomato spotted wilt virus are commercially available. ${ }^{37,38}$ These cultivars have resistance to the tomato spotted wilt virus, but not to thrips feeding or oviposition. All of the commercially available cultivars of tomato share a single source of resistance from the $S w-5$ gene. In pepper, all resistance is conferred by the Tsw gene. Both the $S w-5$ and Tsw genes appear to be single dominant genes, ${ }^{68,69}$ and thus susceptible to being compromised by resistance-breaking strains of the virus. Strains of tomato spotted wilt virus that have overcome resistance from the single-gene dominant trait have appeared in geographical areas outside Florida. ${ }^{70}$ Therefore, an integrated approach is needed to reduce feeding by thrips and the incidence of tomato spotted wilt in order to prevent/minimize the development of resistance-breaking strains of tospoviruses. ${ }^{18}$ In addition, there is a major research effort under way to integrate $S_{w}-7$, another resistance gene, into tomato cultivars, which will improve plant resistance to tomato spotted wilt virus and other tospoviruses (Scott $\mathrm{J}$ and Olson S, unpublished). Currently available cultivars of tomato, including large round determinate types, plum or roma types, large round indeterminate types, large round heritage types and large round grape types, that are resistant to tomato spotted wilt through the $S w-5$ gene are listed in Funderburk et al. ${ }^{37}$

\subsection{Insecticides}

Although the previously mentioned environmentally friendly tactics are a major part of the pest management program, insecticides continue to play an important role in western flower thrips management. Recommendations regarding which insecticides to use and when are made in the context of both shortterm and long-term management goals. Minimizing resistance development and avoiding the flaring of western flower thrips populations by the elimination of natural enemies and competing thrips species are critical factors in insecticide recommendations. The use of selective insecticides against western flower thrips and other pests that have minimal impacts on minute pirate bug populations is very important in conservation biological control in pepper and eggplant. ${ }^{19,20,38,40}$ These insecticides reduce the risk of releasing non-target pests from natural control. ${ }^{19,40}$ Certain carbamate, neonicotinoid and organophosphate insecticides have some level of efficacy against western flower thrips, but these should be used sparingly, and only in particular instances when non-target effects are minimal. Most broad-spectrum synthetic insecticides, including pyrethroids, neonicotinoids, organophosphates and carbamates, kill the native species of thrips that outcompete western flower thrips, $5,40,71$ thereby leading to dramatic large-scale shifts in thrips demographics. ${ }^{8}$ Broadspectrum insecticides can directly enhance the rate of increase in western flower thrips populations. The pyrethroid acrinathrin has been shown to increase the fecundity of resistant western flower thrips females, and survivorship, developmental rates and longevity of progeny can be as great, or greater, than for progeny of susceptible females. ${ }^{72}$ Synthetic broad-spectrum insecticides not only disrupt western flower thrips management, they also disrupt management of other pests, including spider mites, whiteflies and leafminers, by eliminating natural enemies of those pests. ${ }^{73,74}$

In recent years, owing to the unintended harmful side effects of broad-spectrum insecticides, growers have begun to use natural and other reduced-risk insecticides. The spinosyn class is the most efficacious of these insecticides, providing a greater level of control of western flower thrips than all other currently available reduced-risk or broad-spectrum insecticides. ${ }^{20}$ Unfortunately, some level of resistance to spinosyns has been documented in pockets in Florida. ${ }^{43}$ In efforts to sustain the efficacy of spinosyns, no more than two applications of spinosyns per year on the same and sequential crops is recommended. Further, spinosyns should be avoided completely in areas where resistance has developed. These efforts are proving successful, and most monitored populations are returning to susceptibility at the labeled field rate (Srivistava $M$ and Funderburk J, unpublished). ${ }^{43}$

Since 1995, annual evaluations have been made of labeled and promising unlabeled insecticides against populations of western flower thrips, other thrips species and minute pirate bugs in fruiting vegetables. ${ }^{18,19,40,71,75}$ These evaluations, beginning in 2008, have focused on identifying insecticides with varying levels of efficacy against western flower thrips from different chemical IRAC mode of action codes (Srivistava M and Funderburk J, unpublished). IRAC is an insecticide industry association that promotes 'prolonging the effectiveness of insecticides and acaricides by countering resistance problems' (http://www.iraconline.org/about/irac/). Insecticides are classified according to 
their chemistry and mode of action and/or target site (see http://www.irac-online.org/).

Spinosyns have exhibited excellent control of adults and larvae in the locations where the authors' experimental field trials have been conducted. The broad-spectrum acetamiprid, currently labeled for fruiting vegetables, has exhibited a high level of control of adults and larvae. The broad-spectrum experimental tolfenpyrad has also exhibited a high level of control, and a fruiting vegetable label for this insecticide is expected in 2012. The experimental cyantraniliprole has shown high to moderate efficacy against the western flower thrips, and a label for fruiting vegetables is expected in 2012 or 2013. Insecticides that have shown significant suppression of the adults and larvae of western flower thrips include flonicamid, spirotetramat and extract of Chenopodium ambrosioides near ambrosioides. Various commercially available plant extracts and potassium salts of fatty acids have been shown to provide some suppression of western flower thrips on fruiting vegetables. ${ }^{37,38}$ The fact that most of the above-mentioned insecticides are not as efficacious as spinosysns should not prevent their inclusion in integrated pest management programs. The goal of integrated pest management is to prevent damage (i.e. keeping populations below the economic thresholds) rather than killing the maximum number of western flower thrips. By redirecting the focus of management programs to the crop and its optimal production, the producer develops an appreciation for the concept of tolerance of subeconomic levels of pests. This is critical in the widespread adoption of a management approach, as opposed to a control approach, as a more effective, economical and sustainable way to deal with western flower thrips. ${ }^{43,76}$

Bielza $^{72}$ cautioned that simply rotating insecticides from different chemical classes is not the best plan of action to prevent the development of insecticide resistance in the western flower thrips. He outlined a general resistance management protocol that also serves as a foundation for a sound IPM program. The four recommendations are: (1) to apply insecticides only when required; (2) to make accurate and precise insecticide applications; (3) to diversify management methods that are used in a crop; (4) to conserve natural enemies. In addition, resistance monitoring needs to be conducted on an ongoing basis, so that insecticides can be quickly removed from use before complete failures occur, and so that susceptibility to those materials can be restored. Unfortunately, it is found that many growers and their agents incorrectly believe that integrated resistance management is an effective, stand-alone method for preventing the development of resistance in pest populations.

Instead, more effective and sustainable management for western flower thrips and tospoviruses is achieved in the overall context of integrated pest management, with insecticide resistance management being a key component. ${ }^{24}$ Funderburk et al. ${ }^{37,38}$ provide for regularly updated lists of insecticides for fruiting vegetables with varying levels of efficacy against western flower thrips adults and larvae. They recommend rotating available insecticides in different chemical classes to avoid the development of resistance in western flower thrips. ${ }^{20}$ This integrated resistance management strategy is a component of the comprehensive integrated pest management program for fruiting vegetables, and it is only recommended when multiple applications of insecticides are needed for western flower thrips or other pests during the same cropping season.

\subsection{Vertical integration}

The misuse, overuse and unnecessary use of pesticides resulted in the birth of the 'era of integrated pest management' in $1976 .{ }^{77}$ The spread of the western flower thrips and species of tospoviruses has resulted in the worldwide destabilization of established integrated pest management programs for many crops, $^{22}$ and this includes fruiting vegetables grown in Florida. Funderburk ${ }^{20}$ and Weiss et al. ${ }^{43}$ recognized that the situation with western flower thrips in fruiting vegetables in Florida required a shift from managing individual pests to considering the complex of pests with which a grower has to deal. In order to minimize the risk of the development of insecticide resistance, pest resurgences and outbreaks of secondary pests, the present authors are developing and implementing integrated pest management programs that encompass the simultaneous management of multiple pests, regular monitoring of pests and their natural enemies and their antagonists, use of economic or treatment thresholds when applying pesticides and integrated use of multiple suppressive tactics. Ehler ${ }^{78}$ referred to such integration of multiple compatible tactics to control one group of pests (e.g. arthropods or diseases) as 'vertical' integrated pest management.

The conservation biological control program using natural populations of minute pirate bugs to manage western flower thrips has been successfully used by pepper growers in north Florida since the late 1990s, and problems from not only western flower thrips but also whiteflies, aphids and other pests have been fewer and less severe than when growers were following a calendar spray program or frequently using broad-spectrum insecticides in attempts to control the western flower thrips. For example, ladybird beetles (Coccinellidae) are conserved through the conservation biological control program, and this prevents problems from aphids (Reitz SR \& Funderburk $\mathrm{JE}$, unpublished). Conservation biological control is now being successfully implemented for pepper and eggplant in southern Florida.

To enhance further the effectiveness of the conservation biological control program, Funderburk et al. ${ }^{38}$ provide updated information on insecticides labeled for fruiting vegetables that have little impact on populations of minute pirate bugs. It is recommended that only insecticides compatible with biological control be used when necessary for western flower thrips or for other pests until at least fruiting in pepper and eggplant in order to conserve minute pirate bugs. Many broad-spectrum insecticides applied during the vegetative and flowering periods of crop growth can remain toxic to minute pirate bugs and other natural enemies for weeks or months following application. However, the application of broad-spectrum insecticides when necessary during fruiting has merit by reducing the use of reduced-risk insecticides, and thus reducing the risk of resistance developing. This also is the period of crop growth when pepper and eggplant are most vulnerable to outbreak populations of other pests such as pepper weevil (Anthonomus eugenii Cano) and various species of Pentatomidae that are not adequately controlled therapeutically with reduced-risk insecticides. Preventive options are available to reduce the risk of outbreaks of these pests and the need for therapeutic control with broad-spectrum insecticides. $^{38}$

In northern Florida, western flower thrips is the key pest of tomato, and tomato spotted wilt is the most damaging disease. The use of ultraviolet-reflective mulch is effective in reducing populations of western flower thrips and the 
incidence of tomato spotted wilt. Whiteflies and whitefly-vectored viruses are occasional pests in northern Florida, and ultravioletreflective mulch is effective in reducing the damage from these pests. The primary arthropod pest of tomato in southern and central Florida is Bemisia tabaci Genn. Tomato growers in southern and central Florida typically use neonicotinoid and other broad-spectrum insecticides to manage whiteflies and whitefly-vectored viruses, particularly tomato yellow leaf curl virus. However, it is recommended that broad-spectrum insecticides for western flower thrips or other pests be avoided in tomato until fruiting, even though natural populations of minute pirate bugs in tomato are not sufficient for control of the western flower thrips. ${ }^{37,49}$ Broad-spectrum insecticides applied against whiteflies or thrips are frequently responsible for flaring populations of non-target pests, including spider mites and leafminers.

\section{CONCLUSIONS}

Developing and implementing integrated pest management programs is a complex task. It has taken years of research to develop the integrated pest management programs outlined here for western flower thrips in fruiting vegetables. The implementation of these programs is complicated by the fact that fruiting vegetable crops are affected by other pests, and growers must be able to contend with western flower thrips and these other pests effectively. Growers are faced with many decisions that affect their crop management and productivity. Unfortunately, the wrong decision regarding the use of insecticides can result in the elimination of natural biotic resistance factors and in outbreaks of the target and non-target pests.

Clearly, the example of the western flower thrips in fruiting vegetables in Florida illustrates the failure of the control approach, and the need for effective integrated pest management in dealing in the short term and long term with western flower thrips. Over $90 \%$ of growers in Palm Beach County have reported shifting from calendar applications of insecticides to scouting and other recommended integrated pest management practices. ${ }^{76}$ As a result, damage has been reduced, providing these growers with \$US 28.8 million in yield gains and savings in reduced pesticide use. There are clear marketing benefits to the growers employing the integrated pest management approach in that they are able to sell to large retail grocers who demand that the produce not be produced with broad-spectrum insecticides (Amstoy C and Pero F, Pero Farms, Boca Raton, FL, personal communication). Many of the tactics recommended here are suitable for incorporation into low-input, organic and other unconventional production systems. Additional benefits accrue in sustaining the efficacy of reduced-risk insecticides, such as spinosyns. ${ }^{43}$

These integrated pest management programs are knowledgebased systems that are being implemented successfully in different regions of Florida, and they are updated regularly as new research findings become available. This is the result of large research and education investments. There will be a continued need to invest in research to develop additional tactics and to refine these integrated pest management programs to meet emerging challenges and unforeseen problems (e.g. establishment of additional invasive pests and pathogens). There is still a great need continually to train existing users and continually to recruit additional practitioners for expanded future successful implementation of such knowledge-based systems.

\section{REFERENCES}

1 Mound LA, Biological diversity, in Thrips as Crop Pests, ed. by Lewis T. CAB International, Wallingford, Oxon, UK, pp. 197-216 (1997).

2 Childers CC, Feeding and oviposition injuries to plants, in Thrips as Crop Pests, ed. by Lewis T. CAB International, New York, NY, pp. 505-537 (1997).

3 Tomato spotted wilt tospovirus, Impatiens necrotic spot tospovirus and watermelon silver mottle tospovirus. EPPO Bull 34:271-279 (2004).

4 Reitz SR, Seasonal and within plant distribution of Frankliniella thrips (Thysanoptera: Thripidae) in north Florida tomatoes. Fla Entomol 85:431 - 439 (2002)

5 Hansen EA, Funderburk JE, Reitz SR, Ramachandran S, Eger JE and McAuslane $\mathrm{H}$, Within-plant distribution of Frankliniella species (Thysanoptera: Thripidae) and Orius insidiosus (Heteroptera: Anthocoridae) in field pepper. Environ Entomol 32:1035-1044 (2003).

6 Diffie S, Funderburk J, Goldarazena A and Mound L, New North American records for two oriental thrips (Thysanoptera) species. J Entomol Sci 43:128-132 (2008).

7 KirkWDJ and Terry LI, The spread of the western flower thrips Frankliniella occidentalis (Pergande). Agric For Entomol 5:301-310 (2003).

8 Frantz G and Mellinger HC, Shifts in western flower thrips, Frankliniella occidentalis (Thysanoptera: Thripidae), population abundance and crop damage. Fla Entomol 92:29-34 (2009).

9 Pappu HR, Jones RAC and Jain RK, Global status of tospovirus epidemics in diverse cropping systems: successes achieved and challenges ahead. Virus Res 141:219-236 (2009).

10 Webster CG, Reitz SR, Perry KL and Adkins S, A natural M RNA reassortant arising from two species of plant- and insect-infecting bunyaviruses and comparison of its sequence and biological properties to parental species. Virology 413:216-225 (2011).

11 Kirk WDJ, Distribution, abundance and population dynamics, in Thrips as Crop Pests, ed. by Lewis T. CAB International, Wallingford, Oxon, UK, pp. 217-257 (1997).

12 Salguero-Navas VE, Funderburk JE, Beshear RJ, Olson SM and Mack TP, Seasonal patterns of Frankliniella spp. (Thysanoptera: Thripidae) in tomato flowers. J Econ Entomol 84:1818-1822 (1991).

13 Ghidiu GM, Hitchner EM and Funderburk JE, Goldfleck damage to tomato fruit caused by feeding of Frankliniella occidentalis (Thysanoptera: Thripidae). Fla Entomol 89:279-281 (2006).

14 Goldbach R and Peters D, Possible causes of the emergence of tospovirus diseases. Sem Virol 5:113-120 (1994).

15 Parrella G, Gognalons P, Gebre-Selassie K, Vovlas C and Marchoux G, An update of the host range of Tomato spotted wilt virus. J Plant Pathol 85:227-264 (2003).

16 Stumpf CF and Kennedy GG, Effects of tomato spotted wilt virus isolates, host plants, and temperature on survival, size, and development time of Frankliniella occidentalis. Entomol Exp Appl 123:139-147 (2007)

17 Maris PC, Joosten NN, Goldbach RW and Peters D, Tomato spotted wilt virus infection improves host suitability for its vector Frankliniella occidentalis. Phytopathology 94:706-711 (2004).

18 Momol MT, Olson SM, Funderburk JE, Stavisky J and Marois JJ, Integrated management of tomato spotted wilt on field-grown tomatoes. Plant Dis 88:882-890 (2004).

19 Funderburk J, StaviskyJ and Olson S, Predation of Frankliniella occidentalis (Thysanoptera: Thripidae) in field peppers by Orius insidiosus (Hemiptera: Anthocoridae). Environ Entomol 29:376-382 (2000).

20 FunderburkJ, Management of the western flower thrips (Thysanoptera:Thripidae) in fruiting vegetables. Fla Entomol 92:1-6 (2009).

21 Reitz SR and Funderburk J, Management strategies for western flower thrips and the role of insecticides, in Insecticides - Pest Engineering, ed. by Perveen F. InTech, Rijeka, Croatia, pp. 355-384 (2012).

22 Morse JG and Hoddle MS, Invasion biology of thrips. Annu Rev Entomol 51:67-89 (2006).

23 Cloyd RA, Western flower thrips (Frankliniella occidentalis) management on ornamental crops grown in greenhouses: have we reached an impasse? Pest Technol 3:1-9 (2009).

24 Gao Y, Lei Z and Reitz SR, Western flower thrips resistance to insecticides: detection, mechanisms, and management strategies. Pest Manag Sci DOI: 10.1002/ps.3305 (2012). 
25 Rosenheim JA, Johnson MW, Mau RFL, Welter SC and Tabashnik BE, Biochemical preadaptations, founder events, and the evolution of resistance in arthropods. J Econ Entomol 89:263-273 (1996).

26 Broadbent $A B$ and Pree DJ, Resistance to insecticides in populations of Frankliniella occidentalis (Pergande) (Thysanoptera: Thripidae) from greenhouses in the Niagara region of Ontario. Can Entomol 129:907-913 (1997).

27 Zhao G, Liu W, Brown JM and Knowles CO, Insecticide resistance in field and laboratory strains of western flower thrips (Thysanoptera: Thripidae). J Econ Entomo/ 88:1164-1170 (1995).

28 Immaraju JA, Paine TD, Bethke JA, Robb KL and Newman JP, Western flower thrips (Thysanoptera: Thripidae) resistance to insecticides in coastal California greenhouses. J Econ Entomol 85:9-14 (1992).

29 Seaton KA, Cook DF and Hardie DC, The effectiveness of a range of insecticides against western flower thrips (Frankliniella occidentalis) (Thysanoptera: Thripidae) on cut flowers. Aust J Agric Res 48:781-787 (1997).

30 Thalavaisundaram S, Herron GA, Clift AD and Rose $H$, Pyrethroid resistance in Frankliniella occidentalis (Pergande) (Thysanoptera: Thripidae) and implications for its management in Australia. Aust $J$ Entomol 47:64-69 (2008).

31 Espinosa PJ, Bielza P, Contreras J and Lacasa A, Insecticide resistance in field populations of Frankliniella occidentalis (Pergande) in Murcia (south-east Spain). Pest Manag Sci 58:967-971 (2002).

32 Jensen SE, Acetylcholinesterase activity associated with methiocarb resistance in a strain of western flower thrips, Frankliniella occidentalis (Pergande). Pestic Biochem Physiol 61:191-200 (1998).

33 Bielza P, Quinto V, Grávalos C, Abellán J and Fernández E, Lack of fitness costs of insecticide resistance in the western flower thrips (Thysanoptera: Thripidae). J Econ Entomol 101:499-503 (2008).

34 Brødsgaard HF, Insecticide resistance in European and African strains of western flower thrips (Thysanoptera: Thripidae) tested in a new residue-on-glass test. J Econ Entomol 87:1141-1146 (1994).

35 Kontsedalov S, Weintraub PG, Horowitz AR and Ishaayal, Effects of insecticides on immature and adult western flower thrips (Thysanoptera: Thripidae) in Israel. J Econ Entomol 91:1067-1071 (1998).

36 Robb KL, Analysis of Frankliniella occidentalis (Pergande) as a pest of floricultural crops in California greenhouses. PhD Dissertation, University of California, Riverside, CA (1989).

37 Funderburk J, Reitz S, Olson S, Stansly P, Smith H, McAvoy G, et al, Managing thrips and tospoviruses in tomato, ENY-859. Institute of Food and Agricultural Sciences, University of Florida, Gainesville, FL (2011).

38 Funderburk J, Reitz S, Stansly P, Olson S, Sui D, McAvoy G, et al, Managing thrips in pepper and eggplant, ENY-658. Institute of Food and Agricultural Sciences, University of Florida: Gainesville, FL (2011).

39 Hodges A, Digital identification and diagnostics using the platforms of SPDN/NPDN/CPDN: progress and opportunities. Am Entomol 57:231-233 (2011)

40 Reitz SR, Yearby EL, Funderburk JE, Stavisky J, Momol MT and Olson SM, Integrated management tactics for Frankliniella thrips (Thysanoptera: Thripidae) in field-grown pepper. J Econ Entomol 96:1201-1214 (2003).

41 Pedigo LP, Hutchins SH and Higley LG, Economic injury levels in theory and practice. Annu Rev Entomol 31:341-368 (1986).

42 Paini DR, Funderburk JE and Reitz SR, Competitive exclusion of a worldwide invasive pest by a native. Quantifying competition between two phytophagous insects on two host plant species. J Anim Ecol 77:184-190 (2008)

43 Weiss A, Dripps JE and Funderburk J, Assessment of implementation and sustainability of integrated pest management programs. Fla Entomol 92:24-28 (2009).

44 Baezl, Reitz SR and Funderburk JE, Predation by Orius insidiosus (Heteroptera: Anthocoridae) on species and life stages of Frankliniella flower thrips (Thysanoptera: Thripidae) in pepper flowers. Environ Entomol 33:662-670 (2004).

45 Reitz SR, Funderburk JE and Waring SM, Differential predation by the generalist predator Orius insidiosus on congeneric species of thrips that vary in size and behavior. Entomol Exp Appl 119:179-188 (2006).

46 Ramachandran S, Funderburk J, Stavisky J and Olson S, Population abundance and movement of Frankliniella species and Orius insidiosus in field pepper. Agric For Entomol 3:1 -10 (2001).
47 Coll M, Feeding and ovipositing on plants by an omnivorous insect predator. Oecologia 105:214-220 (1996).

48 Pfannenstiel RS and Yeargan KV, Association of predaceous Hemiptera with selected crops. Environ Entomol 27:232-239 (1998).

49 Baez I, Reitz SR, Funderburk JE and Olson SM, Variation within and between Frankliniella thrips species in host plant utilization. J Insect Sci 11:41 (2011).

50 Landis DA, Wratten SD and Gurr GM, Habitat management to conserve natural enemies of arthropod pests in agriculture. Annu Rev Entomol 45:175-201 (2000).

51 Kasina J, Nderitu J, Nyamasyo G, Olubayo F, Waturu C, Obudho E, et al, Evaluation of companion crops for thrips (Thysanoptera: Thripidae) management on French bean Phaseolus vulgaris (Fabaceae). Int $J$ Trop Insect Sci 26:121-125 (2006).

52 Lopez Rand Shepard BM, Arthropods associated with medicinal plants in coastal South Carolina. Insect Sci 14:519-524 (2007).

53 Bottenberg $\mathrm{H}$, Frantz $\mathrm{G}$ and Mellinger $\mathrm{H}$, Refuge and cover crop plantings for beneficial insect habitats. Proc Fla State Hort Soc 112:339-341 (1999).

54 Shirk PD, Shapiro JP, Reitz SR, Thomas JMG, Koenig RL, Hay-Roe M, et al, Predator-prey relationships on Apiaceae at an organic farm. Environ Entomol 41:487-496 (2012).

55 Northfield TD, Paini DR, Funderburk JE and Reitz SR, Annual cycles of Frankliniella spp. (Thysanoptera: Thripidae) thrips abundance on north Florida uncultivated reproductive hosts: predicting possible sources of pest outbreaks. Ann Entomol Soc Am 101:769-778 (2008).

56 Matteson N, Terry I, Ascoli-Christensen A and Gilbert C, Spectral efficiency of the western flower thrips, Frankliniella occidentalis. J Insect Physio/ 38:453-459 (1992).

57 Fanigliulo A, Comes S, Pacella R, Crescenzi A, Momol MT, Olson SM et al, Integrated management of viral diseases in field-grown tomatoes in southern Italy. Acta Hort 808:387-392 (2009).

58 Stapleton JJ and Summers CG, Reflective mulches for management of aphids and aphid-borne virus diseases in late-season cantaloupe (Cucumis melo L. var. cantalupensis). Crop Prot 21:891-898 (2002).

59 Summers CG, Newton AS, Mitchell JP and Stapleton JJ, Population dynamics of arthropods associated with early-season tomato plants as influenced by soil surface microenvironment. Crop Prot 29:249-254 (2010).

60 Lamont WJ, Jr, Plastics: modifying the microclimate for the production of vegetable crops. HortTechnology 15:477-481 (2005).

61 Bloem S and Mizell RF, Tomato IPM in Florida. University of Florida Cooperative Extension Service EDIS Publication, Gainesville, FL, 23 pp. (2004).

62 Harpaz I, Nonpesticidal control of vector-borne viruses, in Pathogens, Vectors and PlantDiseases: Approaches to Control, ed. by Harris KF and Maramorosch K. Academic Press, New York, NY, pp. 1-21 (1982).

63 Maynard DN and Olson SM, Vegetable Production Guide for Florida. University of Florida, IFAS, Florida Cooperative Extension Service, Gainesville, FL (2000).

64 Castro BF, Durden BR, Olson SM and Rhoads FM, Telogia Creek irrigation energy conservation demonstration on mulched staked tomatoes. Proc Fla State Hort Soc 106:219-222 (1993).

65 Brodbeck BV, Stavisky J, Funderburk JE, Andersen PC and Olson SM, Flower nitrogen status and populations of Frankliniella occidentalis feeding on Lycopersicon esculentum. Entomol Exp App/ 99:165-172 (2001).

66 Stavisky J, Funderburk JE, Brodbeck BV, Olson SM and Andersen PC, Population dynamics of Frankliniella spp. and tomato spotted wilt incidence as influenced by cultural management tactics in tomato. J Econ Entomol 95:1216-1221 (2002).

67 Sticher L, Mauch-Mani B and Métraux JP, Systemic acquired resistance. Annu Rev Phytopathol 35:235-270 (1997).

68 Boiteux LS and de Avila AC, Inheritance of a resistance specific to tomato spotted wilt tospovirus in Capsicum chinense 'PI 159236'. Euphytica 75:139-142 (1994).

69 Stevens MR, Scott SJ and Gergerich RC, Inheritance of a gene for resistance to Tomato spotted wilt virus Tswv from Lycopersicon peruvianum Mill. Euphytica 59:9-17 (1992).

70 Roselló S, Díez MJ and Nuez F, Genetics of tomato spotted wilt virus resistance coming from Lycopersicon peruvianum. Eur J Plant Pathol 104:499-509 (1998).

71 Srivistava M, Bosco L, Funderburk J, Olson S and Weiss A, Spinetoram is compatible with the key natural enemy of Frankliniella species thrips in pepper. Plant HIth Prog DOI: 10.1094/PHP-2008-0118-02-RS (2008). 
72 Bielza $\mathrm{P}$, Insecticide resistance management strategies against the western flower thrips, Frankliniella occidentalis. Pest Manag Sci 64:1131-1138 (2008).

73 Armenta R, Martínez AM, Chapman JW, Magallanes R, Goulson D, Caballero P, et al, Impact of a nucleopolyhedrovirus bioinsecticide and selected synthetic insecticides on the abundance of insect natural enemies on maize in southern Mexico. J Econ Entomol 96:649-661 (2003).

74 Gonzalez-Zamora JE, Leira D, Bellido MJ and Avilla C, Evaluation of the effect of different insecticides on the survival and capacity of Eretmocerus mundus Mercet to control Bemisia tabaci (Gennadius) populations. Crop Prot 23:611-618 (2004).

75 Dripps JE, Gomez LE, Weiss AW, Funderburk J, Castro BA and Paroonagian $\mathrm{DL}$, Insecticide rotation as a component of thrips resistance management programs. Resist Pest Manag Newsl 19:32-35 (2010).

76 Sui D and Funderburk J, Western Flower Thrips Monitoring for Pepper (Capsicum annuum) Production. [Online]. Extension Professionals Associations of Florida (2010). Available: http://epaf.ifas.ufl.edu Accessed [18 September 2012].

77 Metcalf RL, Changing role of insecticides in cropping protection. Annu Rev Entomol 25:219-256 (1980).

78 Ehler LE, Integrated pest management (IPM): definition, historical development and implementation, and the other IPM. Pest Manag Sci 62:787-789 (2006). 